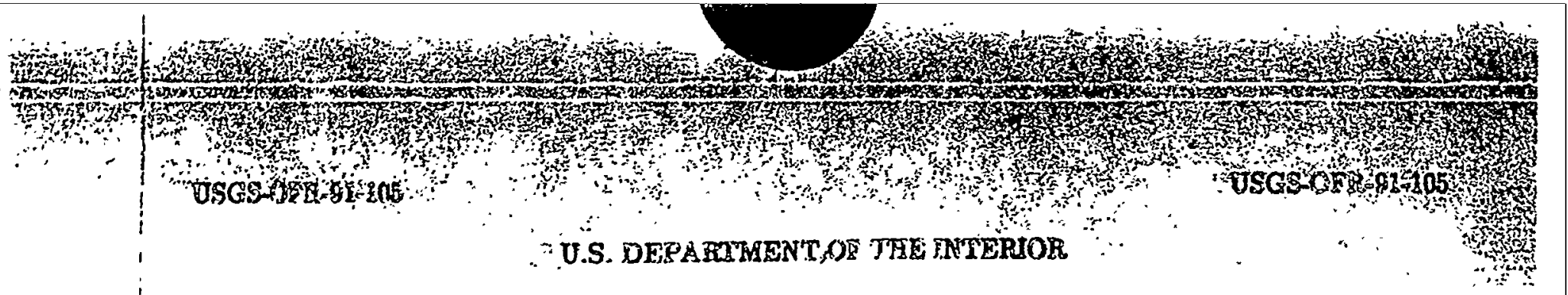

GEOLOGICAI SURVEY

\title{
AEROMAGNETIC MAP OF THE BEATTY QUADRANGLE, NEVADA-CALIFORNIA
}

By

J.M. Glen and D.A. Ponce

1891

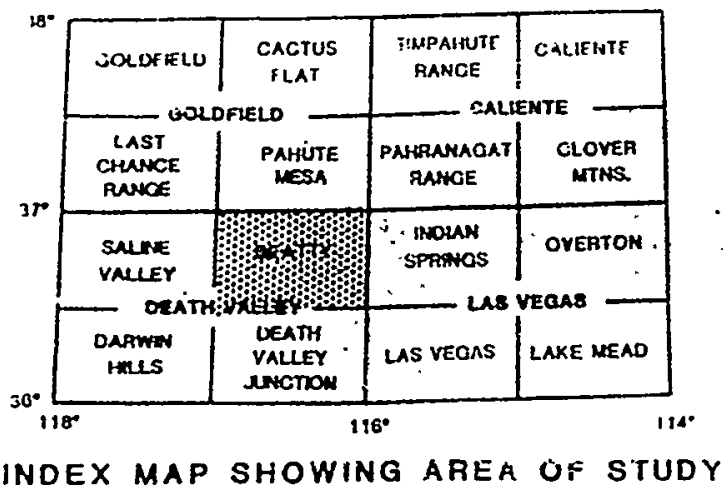

\section{Open-File.Report 91-105}
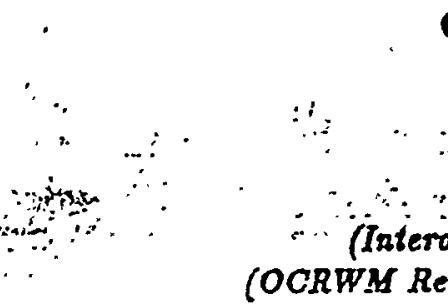

Prepared in cooperation with the $\stackrel{-}{-}$

$\because$ Nevada Operations Office

$\therefore$ U.S. Department of Energy :

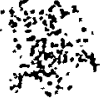

Recordo Management number NNA.920123:0089)

This repart is preliminary and has not been reviewed for conformity with U.S. Geological Survey editorial standards os with the Norin American Stratigraphic Cude. Any use of trade. ïrm, or product names is for descriptive purpoces only snd doea not impiv. endarsement by the U.S. Government.

Menlo Park, California

1991 


\section{DISCLAIMER}

This report was prepared as an account of work sponsored by an agency of the United States Government. Neither the United States Government nor any agency thereof, nor any of their employees, make any warranty, express or implied, or assumes any legal liability or responsibility for the accuracy, completeness, or usefuiness of any information, apparatus, product, or process disclosed, or represents that its use would not infringe privately owned rights. Reference herein to any specific commercial product, process, or service by trade name, trademark, manufacturer, or otherwise does not necessarily constitute or imply its endorsement, recommendation, or favoring by the United States Government or any agency thereof. The views and opinions of authors expressed herein do not necessarily state or reflect those of the United States Government or any agency thereof. 


\section{DISCLAIMER}

Portions of this document may be illegible in electronic image products. Images are produced from the best available original document. 
U.S. DEPARTMENT OF THE INTERIOR

U.S. GEOLOGICAL SURVEY

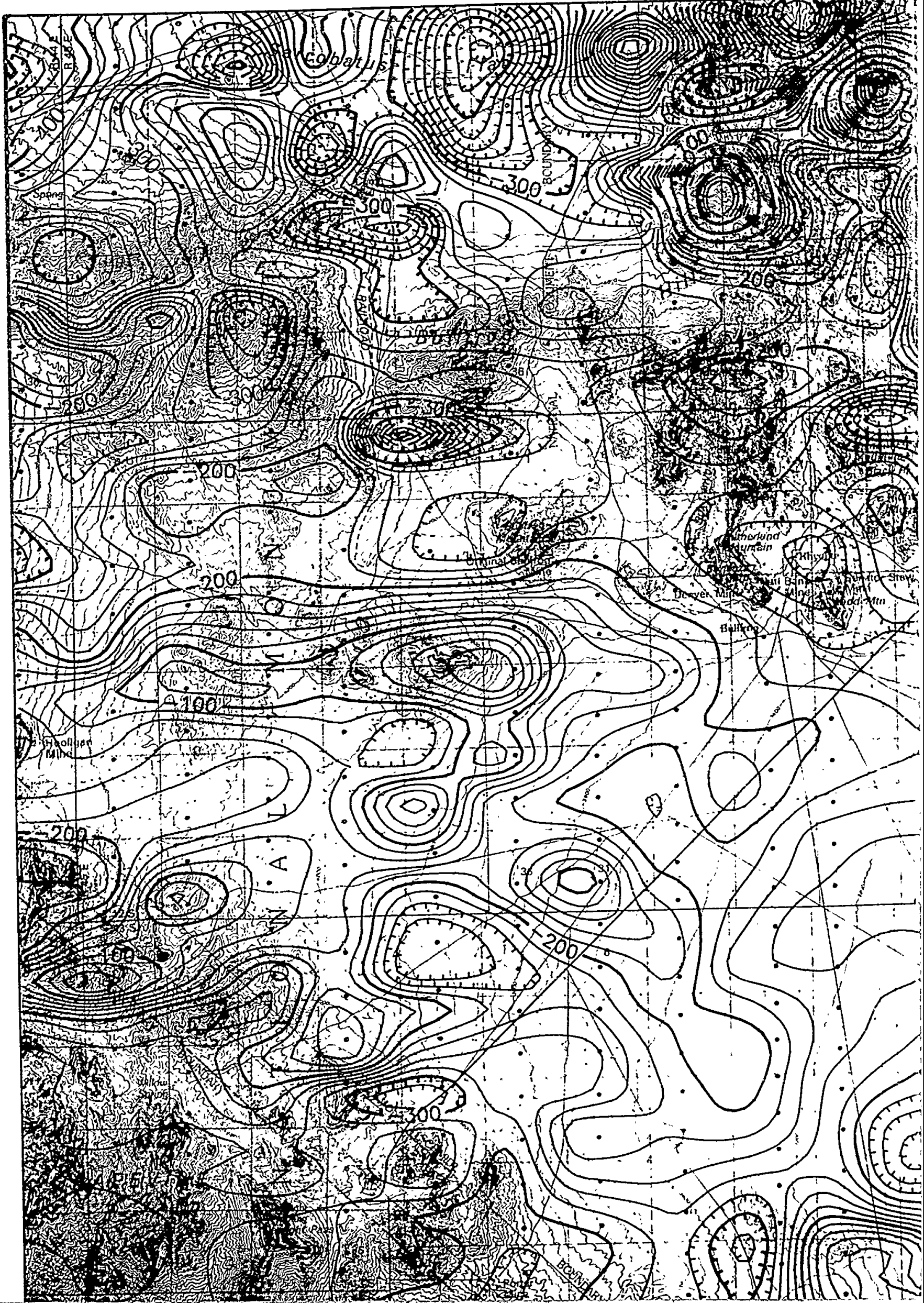


364.

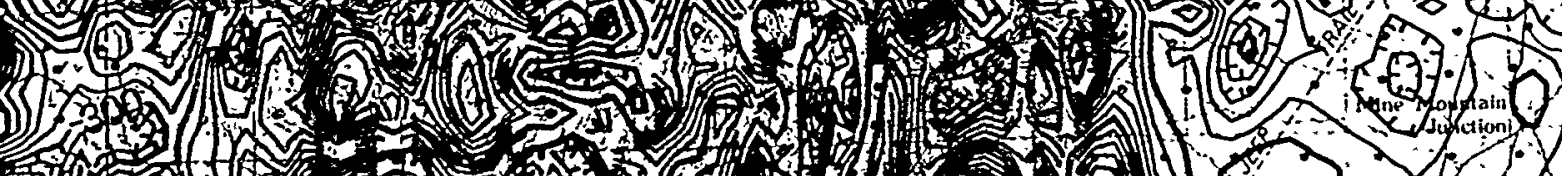
T)

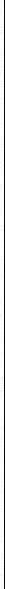
1.

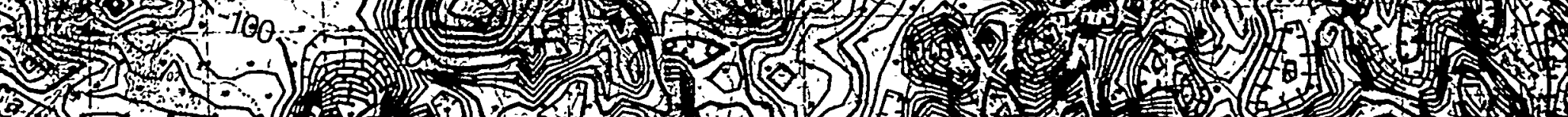
( 
$116^{\circ} 00^{\circ}$

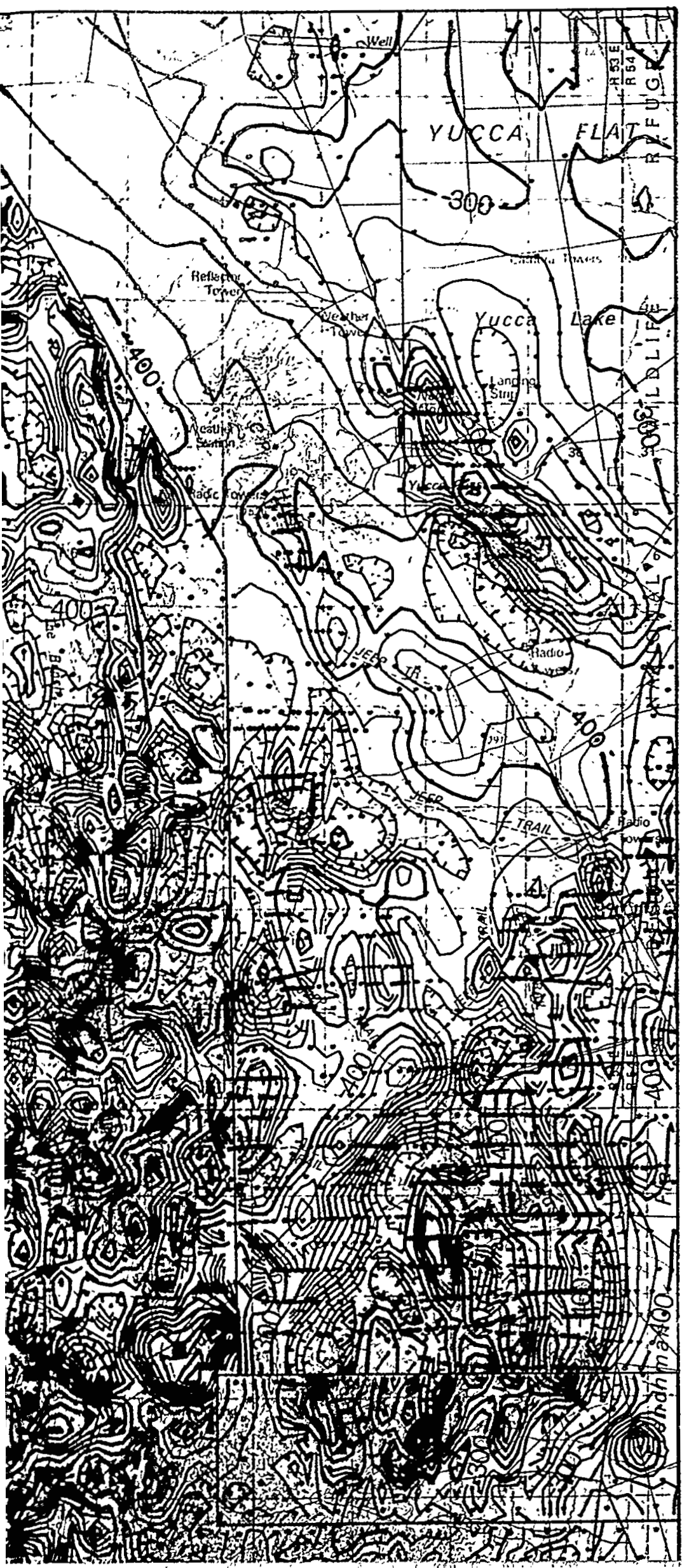

$3700^{\circ}$

is:

DISCUS\$ION

An aeromagnetic map of the Beatty qua from six separate aeromagnetic sulveys (4. fig. 1 and table 1). All available eromag: completely or partly within the Beatty qu figure 2. The map is a mosaic of the mos: cover the quadrangle. Data sets werc chosen the aeromagnetic data and the spacing and $\mathrm{s}$ (table 1). Each data set was compiled from . except for the Yucca Flat survey (4, fig. was digitized.from an unpublished map. (U) unpub. data, 1971). In addition, a revised $y$ Wells survey was used because of positioniz data found in the original data set (Langenh: (15, fig. 1 and table 1$)$.

A regional magnetic gradient, calculat tional Geomagnetic Reference Field (Peddita from each survey except the Yuccal Flat sur: 1). The data were gridded at intervals of spacing in approximately the direction of thi flightline spacing in the perpendicular direc a grid interval of $800 \times 1600 \mathrm{~m}$ for the Las is and table 1) and $200 \times 400 \mathrm{~m}$ for all other $s$ algorithm is based on minimum total curvatu least curvature consistent with the data (Bria datum, referenced to the Timber Mountain table 1) was achieved by adding a constant $t$.

The aeromagnetic map is useful for ida ologic interest and for qualitative or quantiz Although the mosaic map is difficult to qu: across survey boundaries, it preserves the oria survey and allows quantitative assessments of within survey borders. In addition to the : sirable to have a merged map in which sur. continued to a common level, datum adjust: mosaic and merged aeromagnetic maps are tary and together they enable a more compre? of magnetic anomalies. The merged map facil of anomalies that cross survey boundaries an tzrre of the magnetic field. Such a merged m the state of Nevada by Hildenbrand and Kuck contains less detailed data than the Yucca $\mathrm{Fl}_{4}$ surveys shown here $(4,15$; respectively; fig. tional work is required to produce a similar mi the most detailed data.

$1000^{\circ} d$

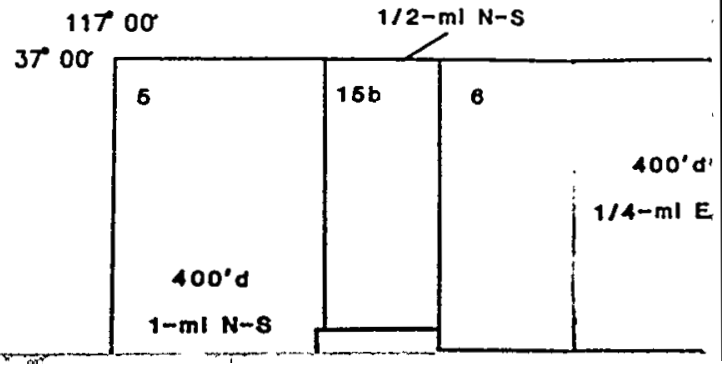




\section{DISCUS\$ION}

ap of the B Batty quadrangle was prepared ragnetic surveys $(4,5,6,9,10$, and 15 ; I available keromagnetic surveys that are inin the Beatty quadrangle are shown in mosaic of the most detailed surveys that ita sets werd chosen based on the quality of id the spacing and altitudes of the surveys was compiled from original contract data, at survey $(4$, fig. 1 and table 1) which npublished map (U.S. Geological Survey, addition, a revised version of the Lathrop ,ecause of positioning errors and missing I data set (Langenheim and others, 1991)

c gradient, / calculated from the Internarrence Field (Peddie, 1982) was removed the Yuccal Flat survey (fig. 1 and table ded at intervals of one-half the flightline the direction of the flight path, and one perpendicular direction. This resulted in $600 \mathrm{~m}$ for the Las Vegas survey $(9, \mathrm{fig} .1$ $100 \mathrm{~m}$ for all other surveys. The gridding nimum totgl curvature which provides the b with the data (Briggs, 1974). A uniform : Timber Mountain survey $(6, \mathrm{fig} .1$ and adding a cbnstant to each survey.

nap is useful for identifying areas of geualitative or quantitative interpretation. ap is difficalt to quantitatively interpret , it preserves the original character of each tative assessments of individual anomalies In addition to the mosaic map, it is de1 map in which surveys are analytically level, datum adjusted, and merged. The nagnetic maps are mutually complemenable a nore comprehensive interpretation he merged map facilitates interpretations Irvey boundaries and yiẹlds a clearer pic1. Such a merged inap was compiled for Idenbrand and ICucks (1988). However, it a than the Yucca Flat and Lathrop Wells 5; respectively; fig. 1 and table 1 ). Addiproduce a similar merged map containing

1000 'd

$2-\mathrm{ml} \mathrm{N}-\mathrm{S}$ $116^{\circ} 00$

$\boldsymbol{6}$ $400^{\circ} \mathrm{d}$ $1 / 4-m I$ E-W

\section{REFERENCES}

Bath, G.D., Jahren, C.E., Rosenbaum, J.G., and Baldwin, M.J., 1983, Magnetic investigations in Geologic and geophysical investigations of the Climax Stock intrusive, Nevada, : U.S. Geological Survey Open-File Report 83-37T, p. 40-i7. (HQS.880517.1862)

Boynton, G.R., and Vargo, J.L., 1963a, Aeromagnetic map of the Cane Spring quadrangle and parts of the Frenchman Lake, Specter Range, and Mercury Quandrangles, Nye County, Nevada: U.S. Geological Survey Geophysical Investigations Map GP-442, scale 1:62,500. (NNA.910506.0172)

Boynton, G.R., and Vargo, J.L., 1963b, Aeromagnetic map of the Topopah Spring quadrangle and part of the Bare Mountain Quadrangle, Nye County, Nevada: U.S. Geological Survey Geophysical Investigations Map GP-440, scale 1:62,500. (NNA.910506.0173)

Briggs, I.C., 1974, Machine contouring using minimum curvature: Geophysics, v. 39, p. 39-48. (NNA.910506.0160)

Geodata International, Inc., 1979, Aerial radiometric and magnetic survey: Death Valley National Topographic Map, Nevada, California: U.S. Department of Energy, Grand Junction Office Report GJBX-164(79), v. 2, scale 1:500,000. (NNA.910506.0175)

Hildenbrand, T.G., and Kucks, R.P., 1988, Total intensity magnetic anomaly map of Nevada: Nevada Bureau of Mines and Geology Map 93A, scale 1:750,000. (NNA.910506.0176)

Kane, M.F., and Bracken, R.E., 1983, Aeromagnetic map of Yucca Mountain and surrounding regions, southwest Nevada: U.S. Geological Survey Open-File Report 83-616, 20 p., scale 1:48,000. (HQS.880517.1290)

Kane, M.F., Webring, M.W., and Bhattacharyya, B.K., 1981, A preliminary analysis of gravity and aeromagnetic surveys of the Timber Mountain Area, southern Nevada: U.S. Geological Survey Open-File Report 81-189, 40 p. (HQS.880517.2727)

Kirchoff, K.S., Ponce, D.A., and Chuchel, B.A., 1989, Preliminary aeromagnetic map of the Nevada Test Site and vicinity, Nevada: U.S. Geological Survey Open-File Report 89-446, scale 1:100,000. (NNA.900706.0341)

Langenheim, V.E., Carle, S.F., Ponce, D.A., and Phillips, J.D., 1991, Revision of an aeromagnetic survey of the Lathrop Wells area, Nevada: U.S. Geological Survey Open-File Report 91-46, scale $1: 62,500,3$ sheets, 17 p. (NNA.910411.0079)

Peddie, N.W., 1982, International Geomagnetic Reference Field: the third generation: Journal of Geomagnetism and Geoelectricity, v. 34, p. 309-326 (NNA.910814.0006) 
(15)

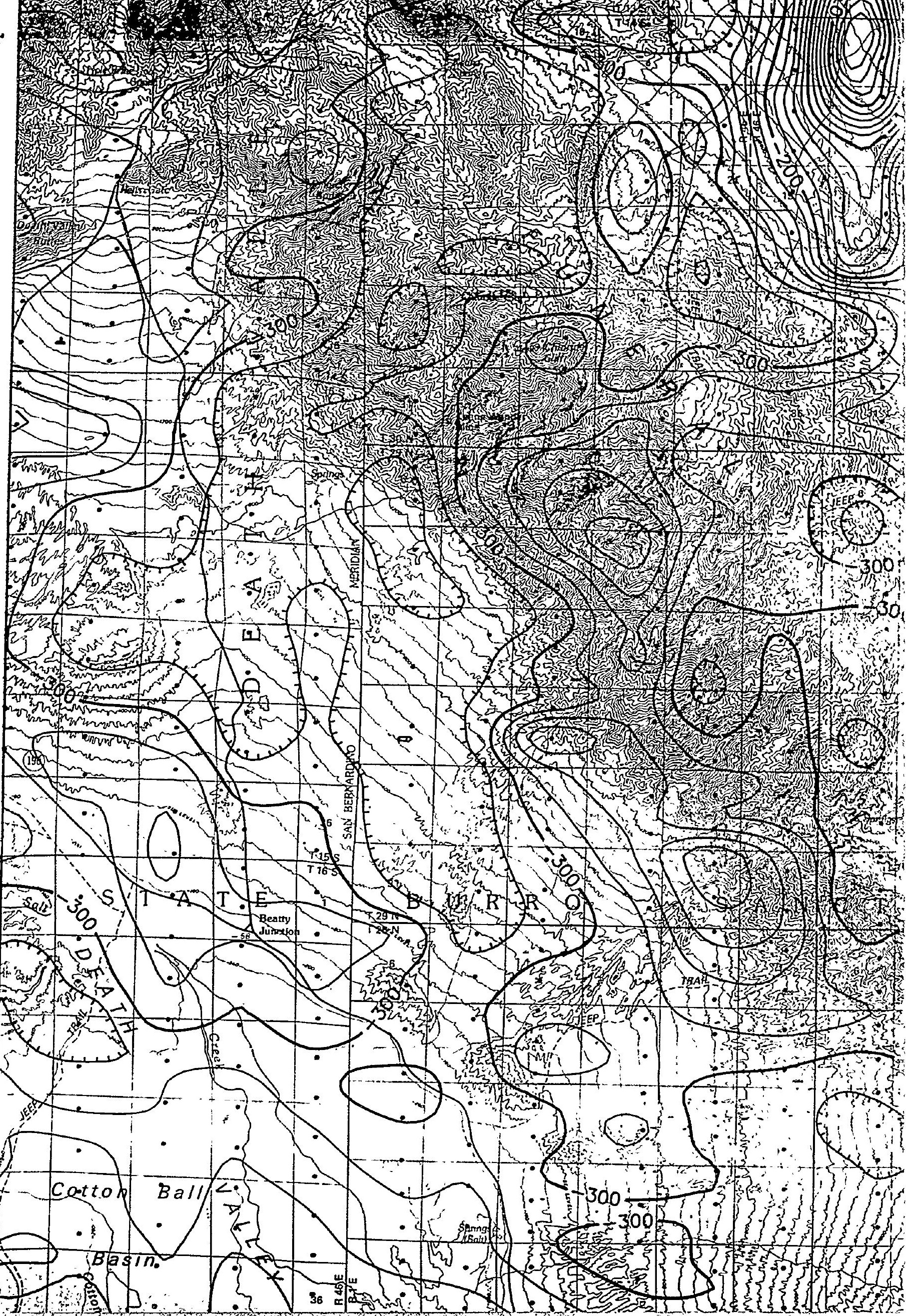



(1) re
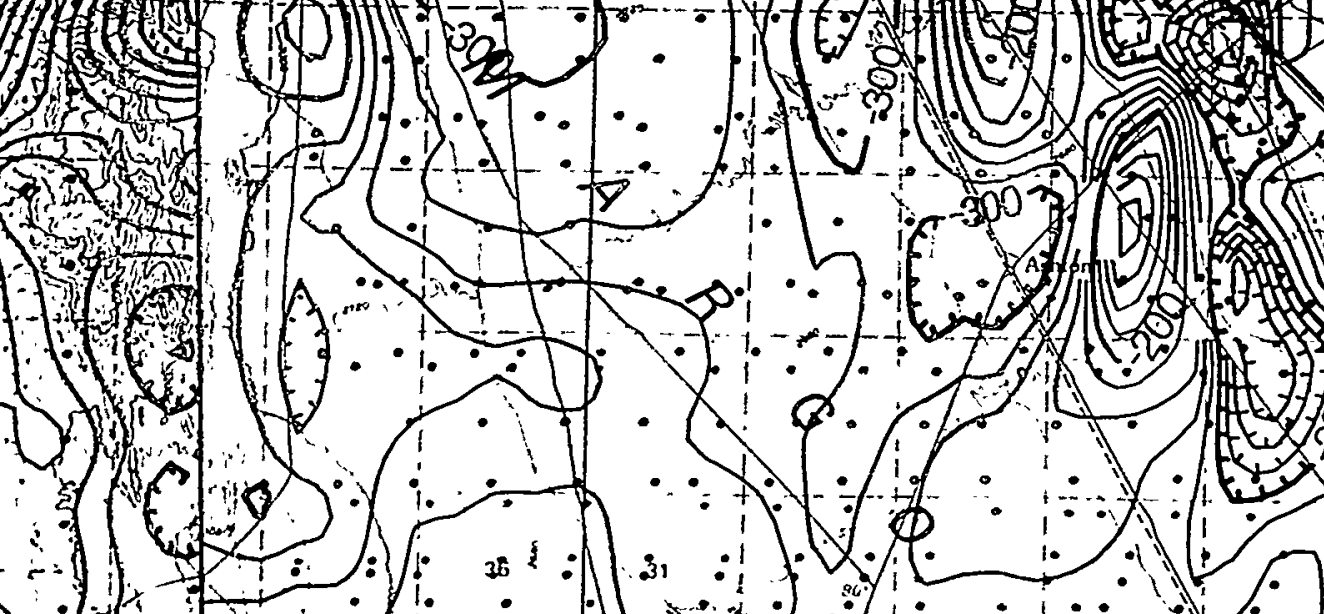

Fiot
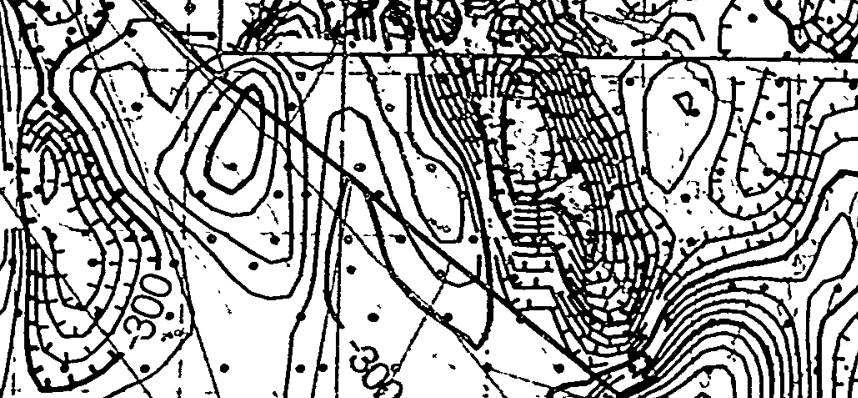

(10)

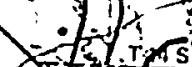

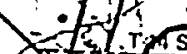

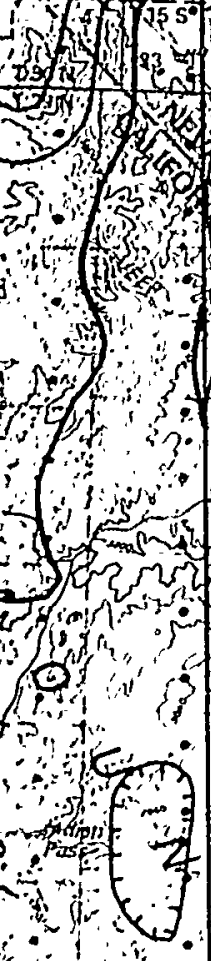
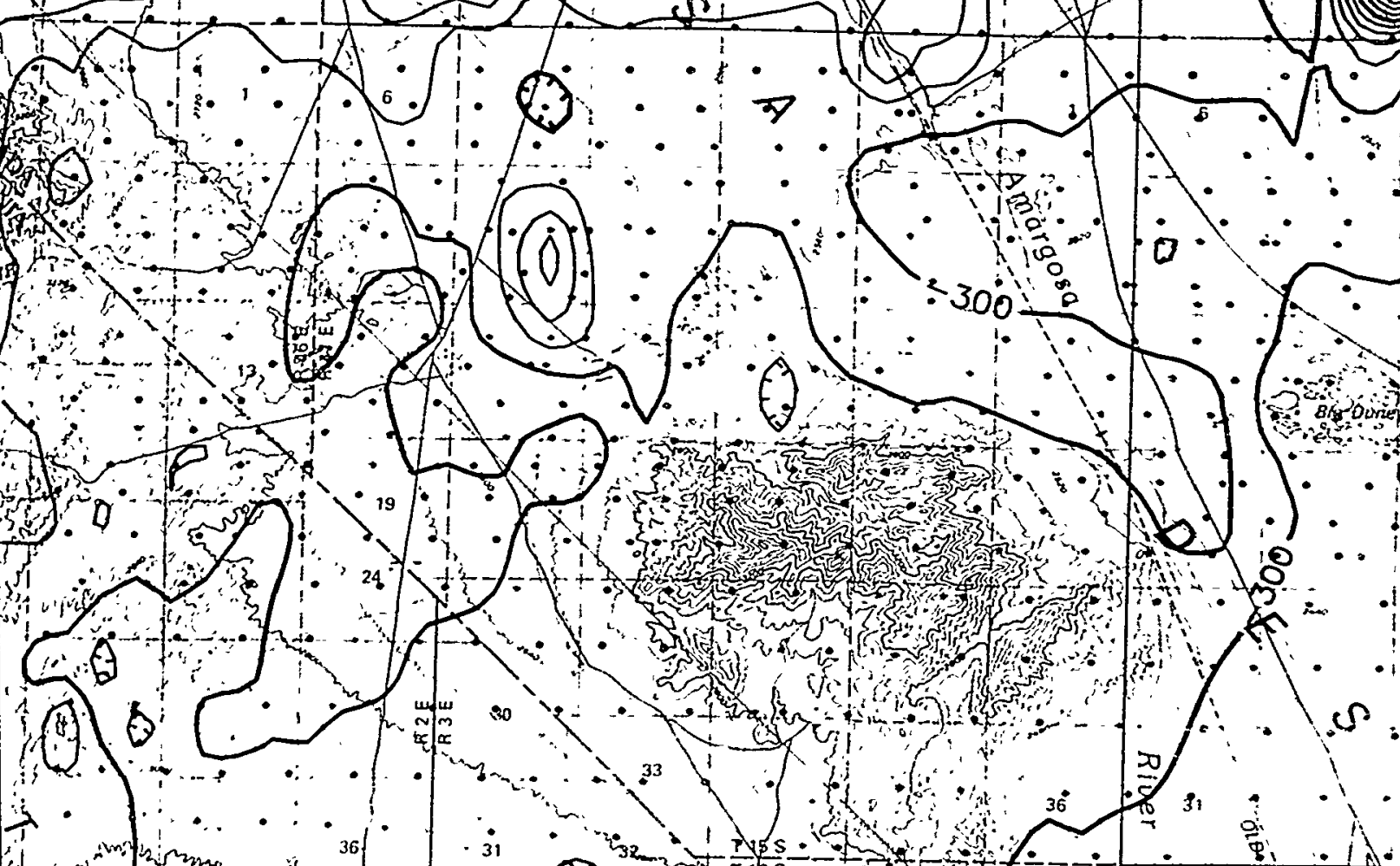

A.
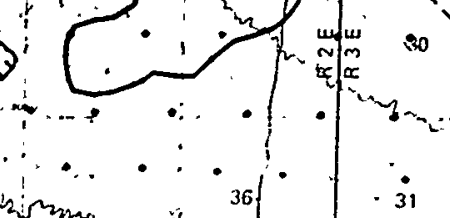

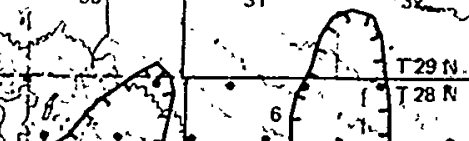

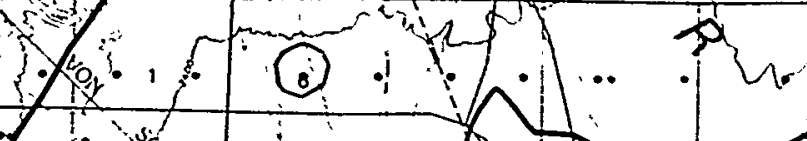

(1) (2)

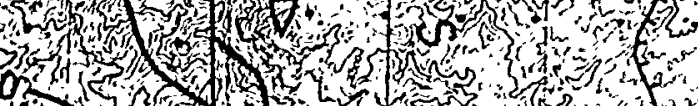
(6) (1) a 63 \%

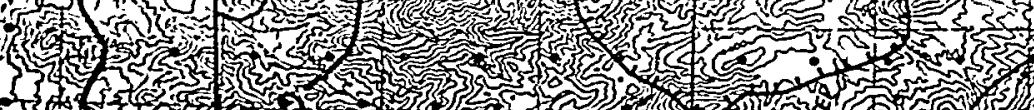

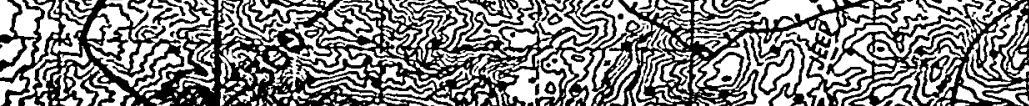



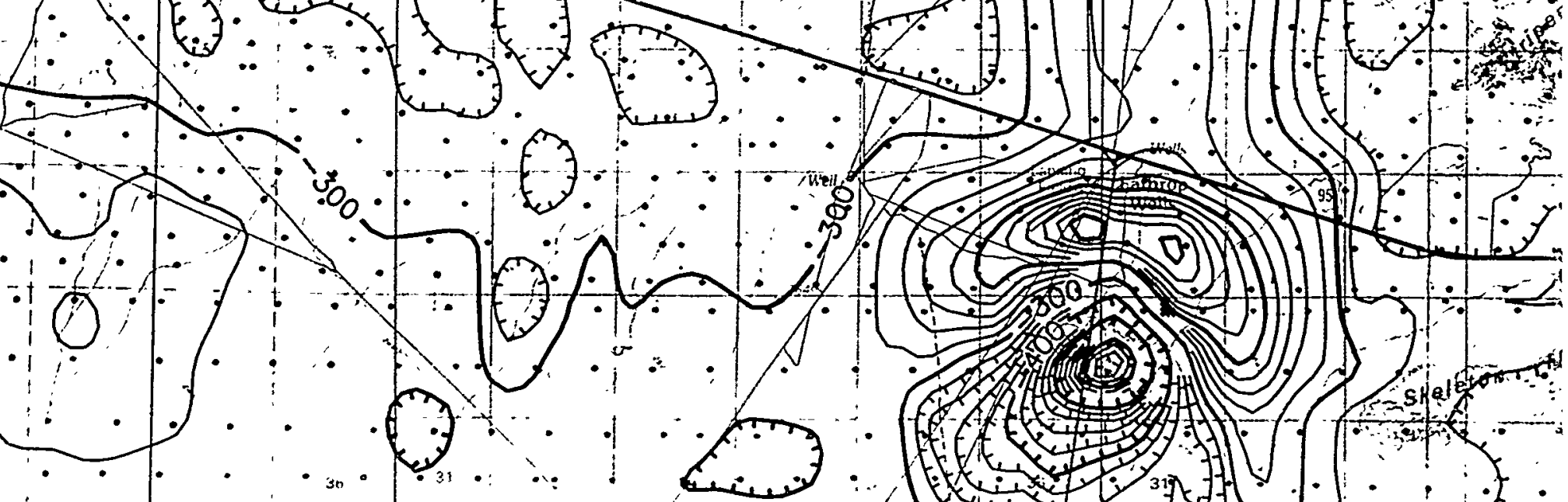

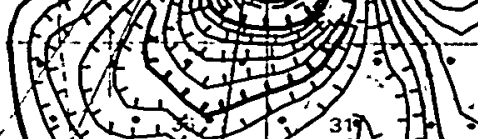

h
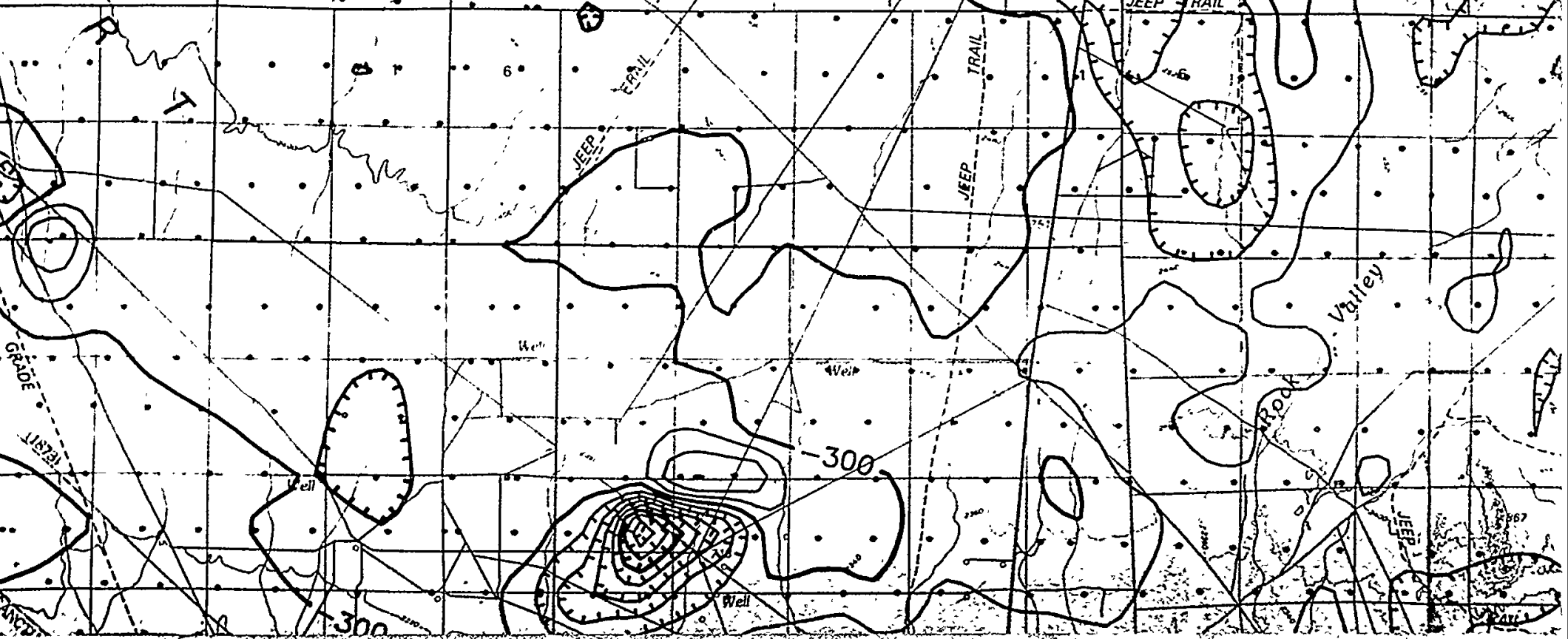

$E y$ 
(X)

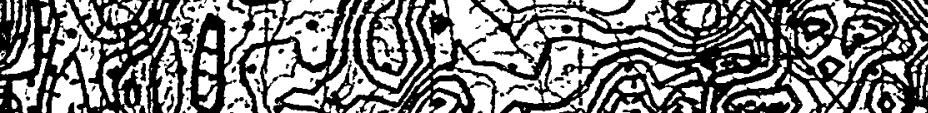
(1)

)

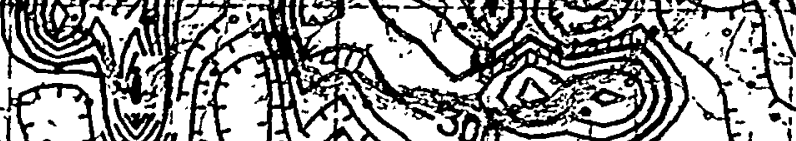

1)

ay 
(1) (3) Q 15.

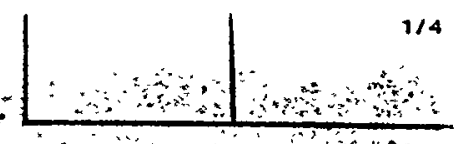

Figures 1.-Index map showing boundaries for surveys used in th. mep of the Beatty quadrangle.

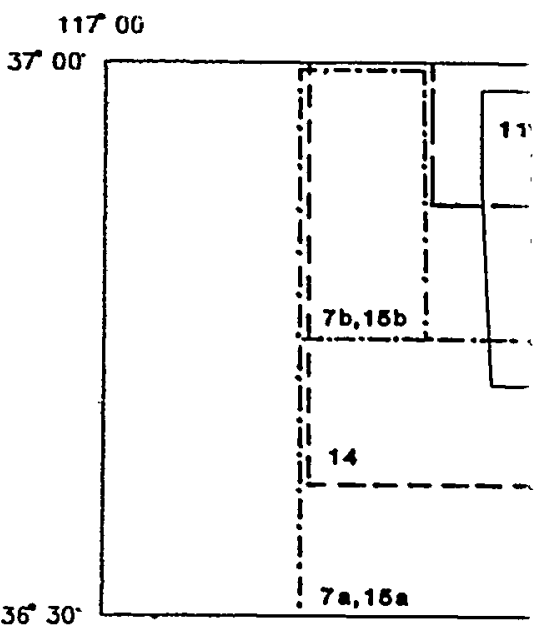

11700

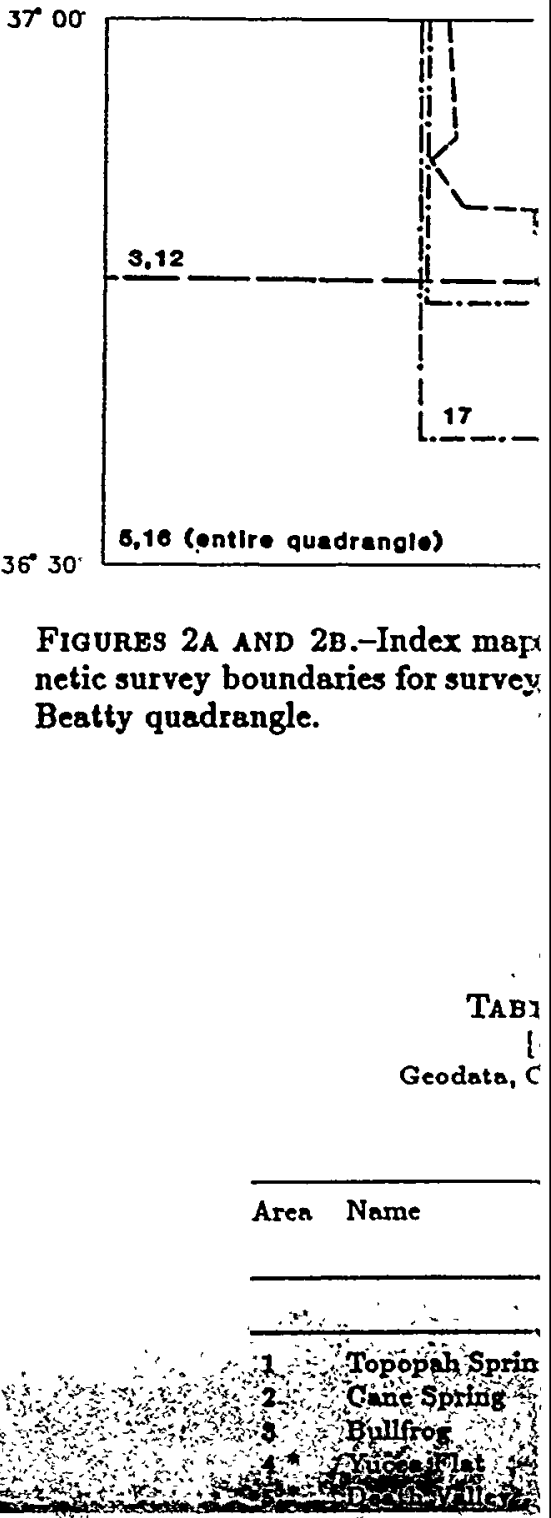




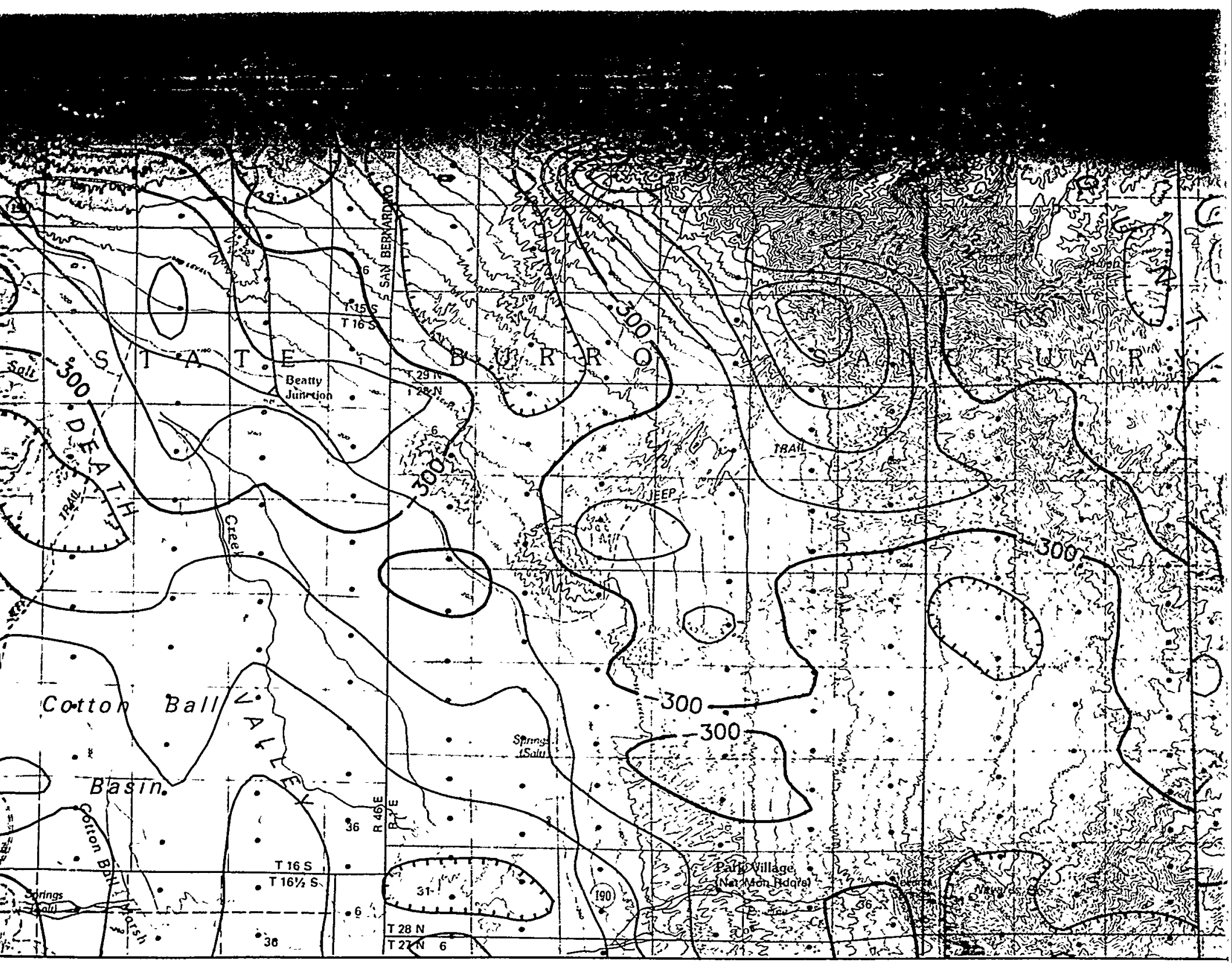

se from U.S. Geological Survey 00,000 Beatty, 1078.

iversal Transverse Mercator se latitude $36^{\circ} 45^{\prime} \mathrm{N}$.

atral meridian long $116^{\circ} 30^{\prime} \mathrm{W}$.

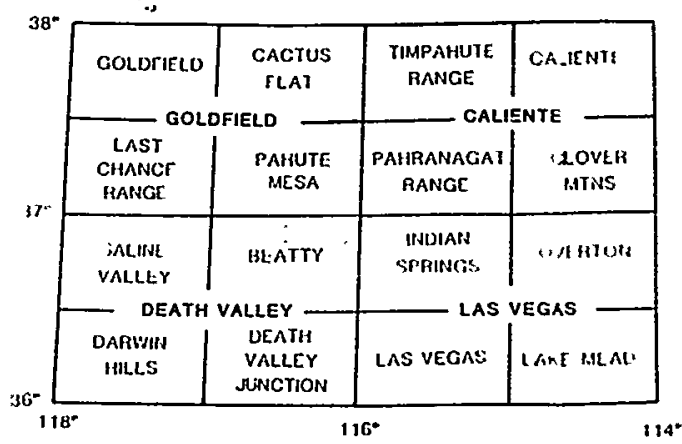

NEV: 


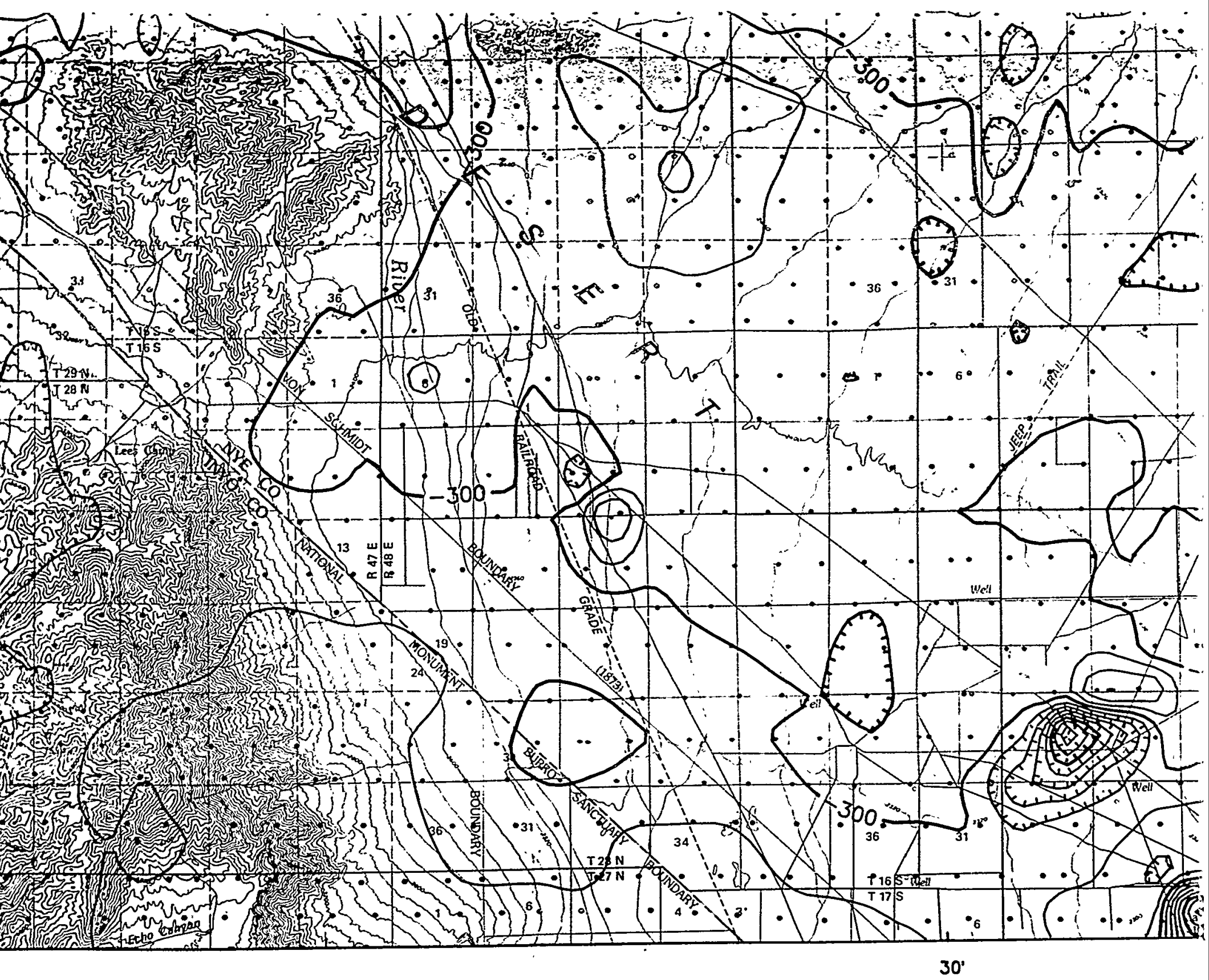

SCALE 1:100 000

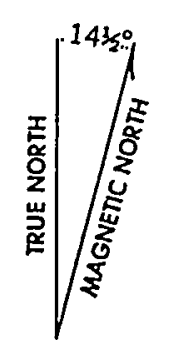

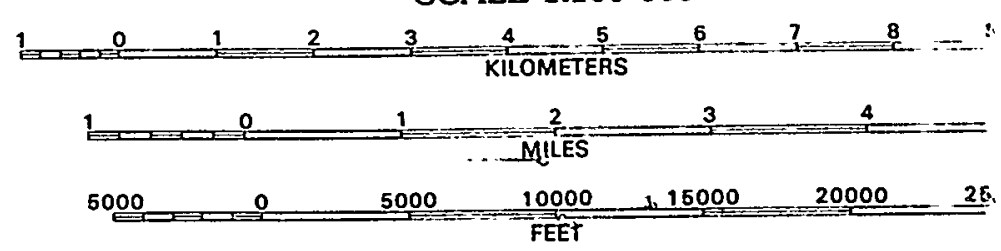

ELEVATION CONTOUR INTERVAL 50 METERS: 

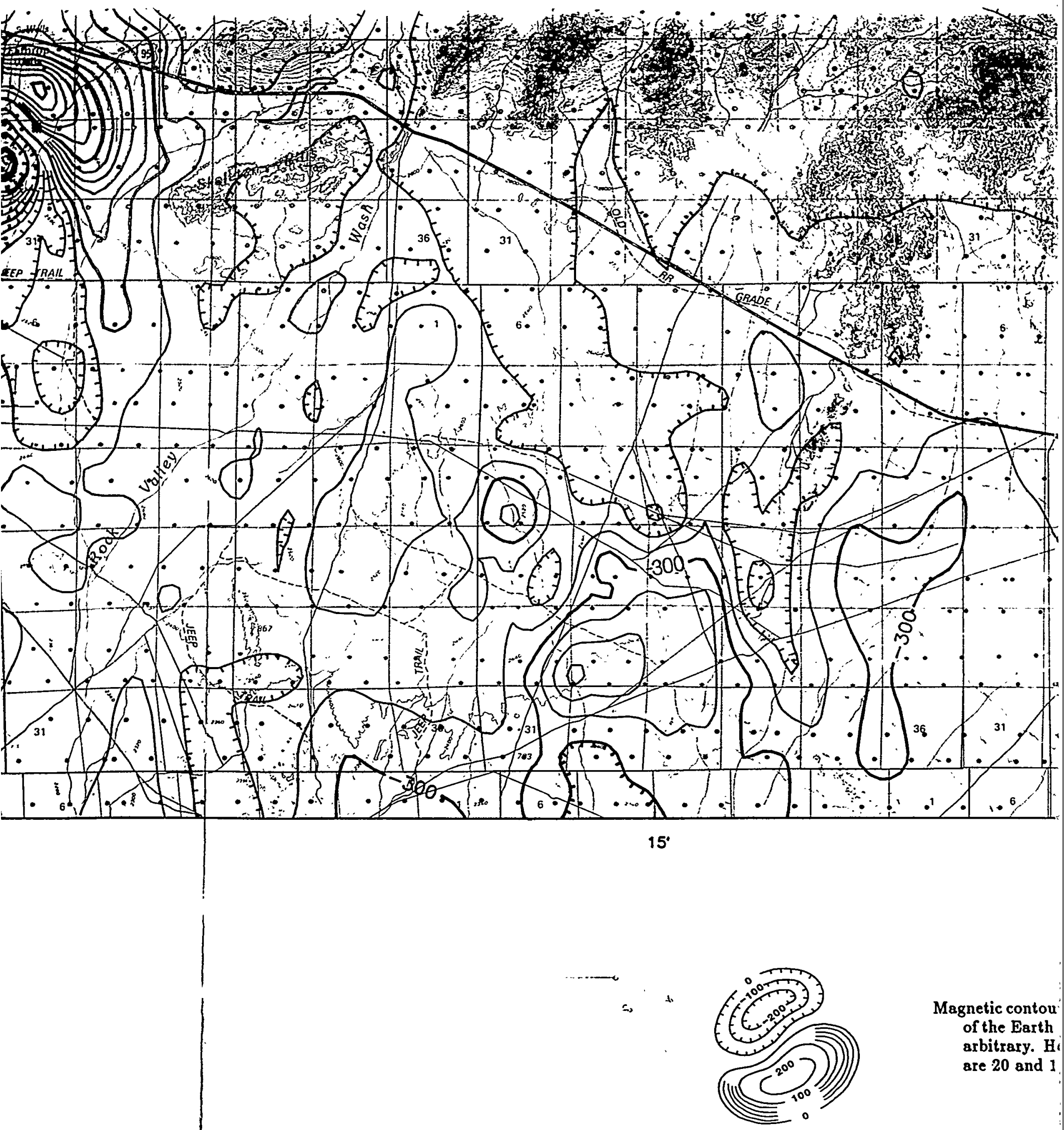

Magnetic contou' of the Earth arbitrary. Hi
are 20 and 1.

Flight path-sh، point along digitized fro
contourline $\mathbf{i}$ 


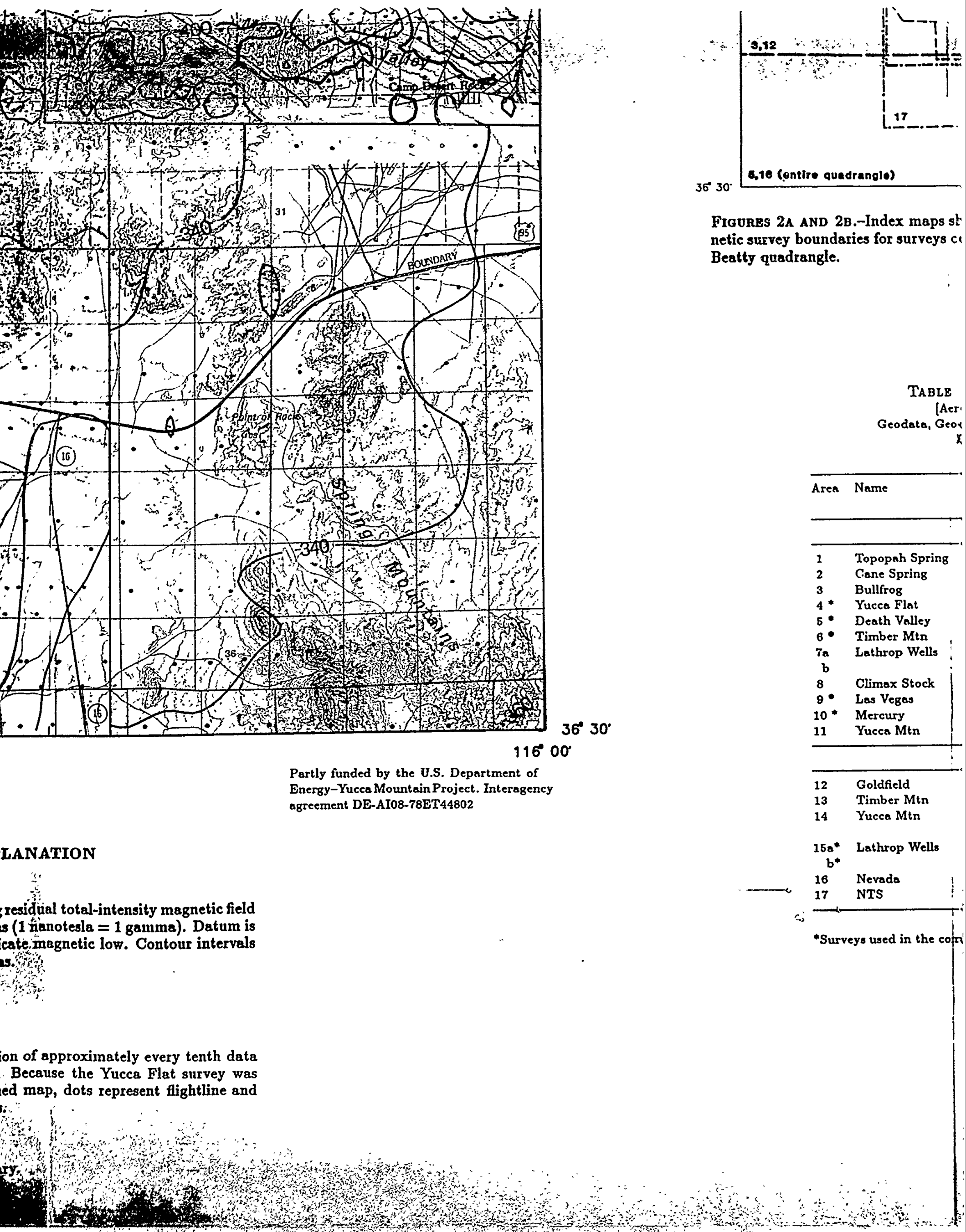


